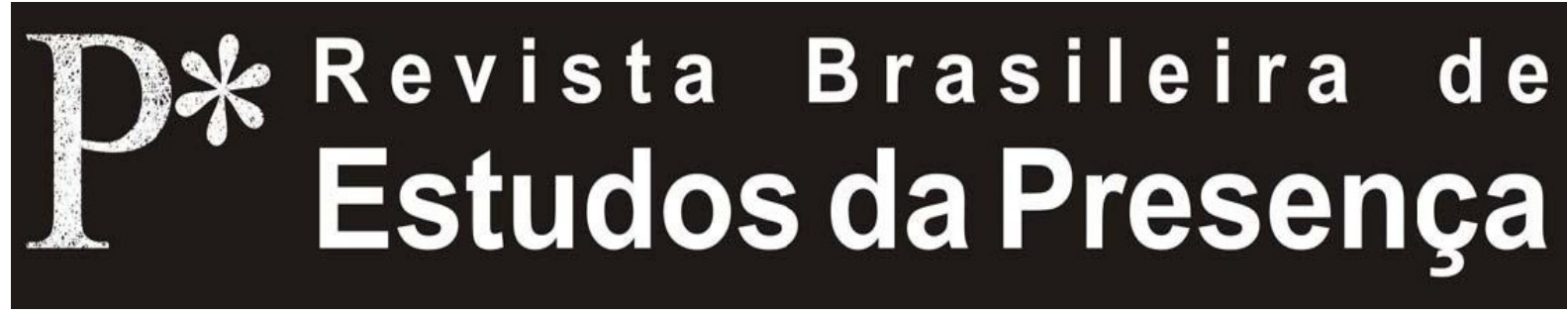

DOI - http://dx.doi.org/10.1590/2237-266037048

ISSN 2237-2660

\title{
Rastros que Emulam Figuras: a montagem de Improviso de Ohio, de Samuel Beckett
}

\author{
Luiz Marfuz \\ Universidade Federal da Bahia - UFBA, Salvador/BA, Brasil
}

RESUMO - Rastros que emulam Figuras: a montagem de Improviso de Obio, de Samuel Beckett - Este texto examina, sob o ponto de vista da genética teatral, os princípios e procedimentos que nortearam a encenação da peça Improviso de Ohio, de Samuel Beckett, com tradução da escritora e dramaturga Cleise Mendes. A análise contempla os elementos textuais, sonoros e visuais da montagem, dirigida pelo autor deste artigo, com ênfase nos rastros do percurso criativo: esboços, fotos, depoimentos, críticas e maquetes, que constituem o que se convencionou chamar de protoencenaçáo, como equivalência ao termo prototexto.

Palavras-chave: Beckett. Encenação. Genética Teatral. Improviso de Ohio. Teatro.

ABSTRACT - Traces that Emulate Figures: the staging of Samuel Beckett's Obio Impromptu - This text examines, from the point of view of theatrical genetics, principles and procedures which guided the staging of Ohio Impromptu, a play by Samuel Beckett, translated by novelist and playwright Cleise Mendes. The analysis includes textual, audible and visual elements of the staging, directed by the author of this article, with emphasis on the traces of the creative process: drafts, photos, testimonials, critiques and mockups, which constitute the so-called proto-staging, as equivalent to the term prototext.

Keywords: Beckett. Staging. Theatrical Genetics. Ohio Impromptu. Theatre.

RÉSUMÉ - Traces qui Émulent Figures: la mise en scène d'Obio Impromptu, de Samuel Beckett - Cet article examine, du point de vue de la génétique théâtrale, les principes et les procédés ayant guidé la mise en scène de la pièce Ohio Impromptu, de Samuel Beckett, avec la traduction du romancier et dramaturge Cleise Mendes. Lanalyse prend en compte les éléments textuels, sonores et visuels du spectacle, mis en scène par l'auteur de cet article, en mettant l'accent sur les traces du cheminement de la création : croquis, photos, témoignages, critiques et maquettes. Un ensemble qui constitue ce qu'on appelle la proto mise en scène, un équivalent du terme prototexte.

Mots-clés: Beckett. Mise en Scène. Génétique Théâtral. Ohio Impromptu. Théâtre. 
Falar da própria experiência artística e distanciar-se para examiná-la criticamente é se colocar no embate com a linguagem. Dizer de si no presente subjetivo emocionaliza o relato, mas lhe dá suposta credibilidade. E o exercício de falar de si como se fosse outro, distanciado do objeto no decurso temporal, é uma espécie de "ilusão de controle temporário" - só para utilizar, em outro contexto, a expressão de Williams (2002, p. 189) ao falar dos impasses e aporias no drama moderno -, porque narrador e narrado estão ali, dissolvidos no mesmo sujeito.

Esta análise a que me proponho - a experiência de montagem de Improviso de Ohio, de Samuel Beckett, dirigida por mim, em Salvador, Bahia, em 2004 - desdobra-se em outras, mas se encaminha para dobrar-se sobre si; o que me faz tornar ator e descritor. Como ator sou o objeto que se presta ao olhar do outro. E, descritor, sou o olho que me espreita e procura - em rastros, feridas e cicatrizes -, as imperfeiçóes e possíveis acertos de uma experiência artística como prova de exercício crítico. Mas é da conjunção destes dois olhares, por natureza instáveis e imprecisos, aos quais se somam tantos outros, que se compóe o tecido desta experiência.

Barthes fala de si, em Roland Barthes por Roland Barthes, e pede que tudo seja considerado como se fosse dito por uma personagem de romance (Barthes, 1977). Esta é uma das saídas do impasse: recusar o eu e ocultar-se no ele. São disfarces da linguagem para tentar dizer a mesma coisa. Escolher, por exemplo, comportar-se como certos personagens de Beckett que falam na terceira pessoa para falar de si. Finge-se, assim, que há imparcialidade, quando, no fundo, se está implicado na subjetividade do relato, da qual náo se pode escapar. Como criador e espectador do produzido, distanciado no tempo e no espaço, disponho de memória e imagens, que permanecem flutuantes, jeito torto de operar a bifurcação entre a poética (sentido do fazer) e a estética (sentido de apreciar). Contudo, por mais que me distancie, náo o posso de todo. E, por mais que tudo veja com o olhar de quem o fez, este será sempre incompleto.

A zona de insegurança que integra a cartografia beckettiana é plena de armadilhas constituídas de assombrosas imagens e cirúrgicas palavras, que transtornam a capacidade da linguagem de exprimir a representação. Esse impasse é examinado por Foucault, quando descreve e analisa o quadro As meninas, de Velásquez, ao mostrar os abismos entre linguagem e representação: 
[...] por mais que se diga o que se vê, o que se vê não se aloja jamais no que se diz, e por mais que se faça ver o que se está dizendo por imagens, metáforas, comparações, o lugar onde estas resplandecem náo é aquele que os olhos descortinam, mas aquele que as sucessões de sintaxes definem (Foucault, 1995, p. 25).

Trata-se do mesmo impasse diante do qual Wittgenstein se coloca ao se interrogar sobre a incapacidade da linguagem para cumprir tal função. Como seria, exemplifica o filósofo, explicar a alguém a experiência de ouvir e compreender uma peça musical? Por palavras? Gestos? Dançar expressivamente? Mas ele conclui que não há uma "forma superior", como antes se pensava existir, equivalente a uma linguagem primária a que tudo logicamente pudesse explicar². Daí ser necessário lançar mão de metáforas e analogias para mostrar a experiência estética. E se, porventura, isto não for suficiente, há de se encontrar algum consolo nas palavras de Beckett (2001, p.169): “[...] a linguagem é mais eficientemente empregada quando mal empregada”.

\section{Capturaçáo do Efêmero: a linguagem rebatida na cena}

Improviso de Ohio, peça curta de Samuel Beckett, denominada dramatículo, integrou o espetáculo Comédia do Fim, composto de mais quatro outros textos curtos do autor: Eu não, Fragmentos de teatro I, Comédia e Catástrofe, todos traduzidos pela dramaturga e escritora Cleise Mendes. A estreia ocorreu em 05 de novembro de 2008, no Teatro Castro Alves (Sala do Coro), em Salvador, Bahia, e integrou o teatro de repertório do Núcleo do TCA ${ }^{3}$. Escrita em 1981, publicada em 1982, a peça se presta a inúmeras interpretaçóes e possibilidades de leitura.

Mesmo com o risco de construir uma visão particular, é necessário apresentar a situação da peça, para breve entendimento do leitor, a partir das rubricas: duas figuras - Ouvinte e Leitor - tão semelhantes quanto possíveis, com longos cabelos brancos, estáo sentadas numa mesa, ambos com a cabeça inclinada, apoiada na mão direita. O Leitor tem diante de si um grande livro aberto. Ele conta mais uma vez uma mesma história para o Ouvinte, que apenas reage com batidas na mesa. A cada batida o Leitor retorna ou avança páginas do livro. Ao final, o Leitor fecha o livro e diz: "Não resta nada a dizer"; entáo, ambos, juntos, póem a mão direita sobre a mesa, levantam a cabeça e se olham, fixamente, sem expressáo (Figura 1). 


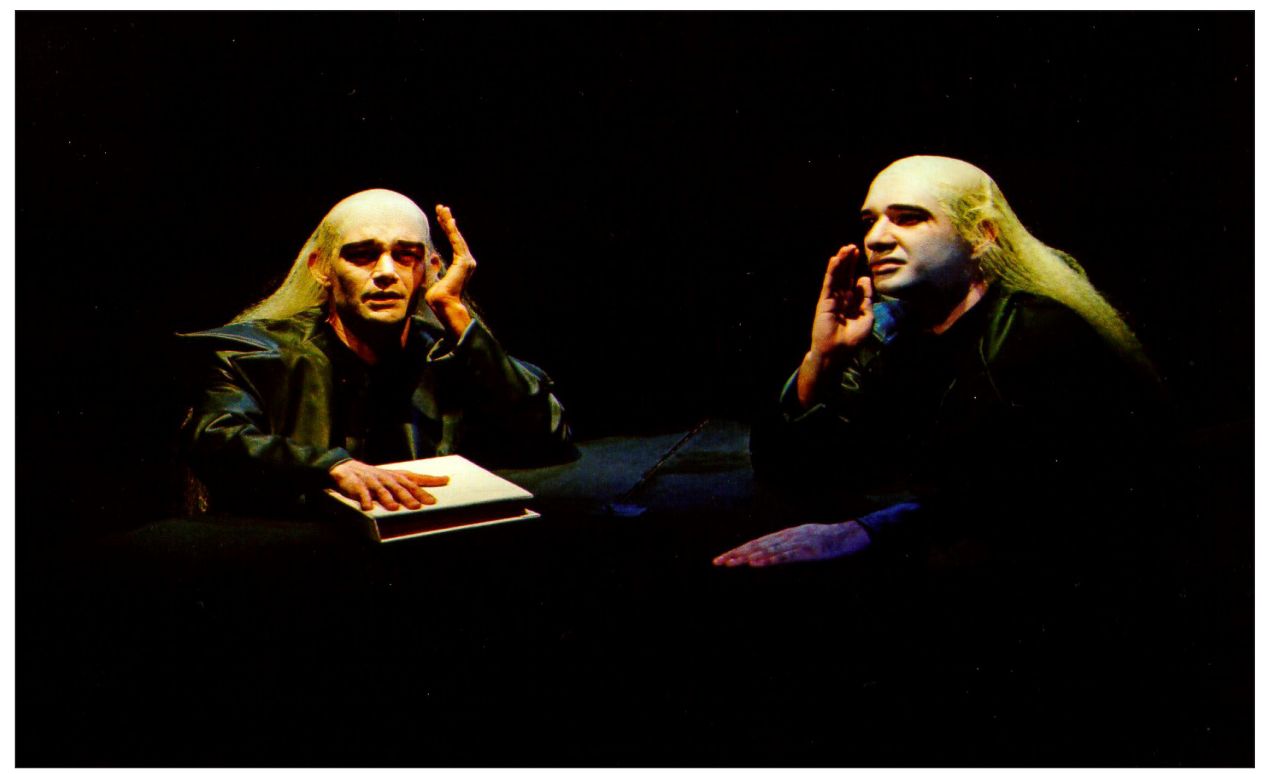

Figura 1: Cena de Improviso de Ohio, na montagem de Comédia do Fim, Sala do Coro do TCA, Salvador, Bahia. Foto: Adenor Gondim.

Variadas interpretaçóes podem ser extraídas desta situação: uma história de amor revivida e lembrada pelas duas figuras como um mise en abyme; mundos divididos em falantes (Leitor) e silentes (Ouvinte); um exercício meramente musical arquitetado por palavras, pausas, silêncio e batidas na mesa, ou, como examina Leyla PerroneMoisés, um consolatio ${ }^{4}$ que trata da "[...] perda de um ser amado. Da relação a dois, amante e amado (a), quando só resta um, a sós com uma sombra. Do passado lido a dois num mesmo livro, até a exaustão da história" (Perrone-Moysés, 1996, p. 5). Toda e qualquer leitura é possível e todas, possivelmente, seriam desautorizadas pelo autor, avesso ao significado fechado que pretendiam imprimir em seus textos: "A chave de minhas peças é talvez", diz Beckett ${ }^{5}$.

Sabe-se que o estudo dos textos e a farta produção hermenêutica sobre a poética beckettiana tanto podem enriquecer o olhar do encenador quanto encastelá-lo no rigor de princípios e interpretaçóes: são os vazios do texto, constituídos pela linguagem que o enforma; vãos que esperam ser preenchidos em cada encenação. Quando Walter Asmus, um dos diretores-assistentes de Beckett, tenta repetir o caminho de dramaturgo-encenador irlandês, na montagem de Esperando Godot, em 1979, em Nova York, e reconhece que falha, afirma que foi obrigado a encontrar o próprio método para a montagem do mesmo texto (Asmus, 1997, p. 42). 
Este exemplo mostra o estado de desorientação que toma conta dos encenadores que se propóem a montar peças do dramaturgo irlandês, ainda quando se conheça minuciosamente as estratégias de montagem, registradas nos cadernos de direção dos textos que Beckett dirigiu. $\mathrm{Na}$ arte, o método é um leme para se navegar em tempestades, mas estas não são iguais. Em alto mar, nunca se sabe o desconhecido que se aproxima do barco. Na cena beckettiana, certezas caem. Para o encenador paulista Rubens Rushe, o processo de ensaio de um texto de Beckett é o esgotamento de todas as possibilidades. Segundo ele, "[...] náo adianta sentar-se numa mesa e discutir Dante, Schopenhauer, pois a sensação é a de que nada se sabe, uma vez que o desconforto e a desorientaçáo se apossam do encenador" (Rushe, 2002, entrevista).

Por isso mesmo, as referências da genética teatral, eivadas da subjetividade da experiência criativa e associada a um olhar crítico, podem fornecer pistas para elucidar o itinerário formador da encenação, constituído de rascunhos, esboços visuais, maquetes, gráficos, falas múltiplas, avanços e recuos estratégicos. De início, já se encontra numa zona pantanosa, na qual o texto teatral em si já deriva de um prototexto, como assinala Camargo (2008, p. 282), ao estabelecer relaçóes entre a crítica genética literária e a teatral:

O texto teatral escrito, publicado ou não, na perspectiva da sua encenação, é, para a equipe técnico-artística encarregada de sua concretizaçáo, um prototexto. Prototexto, do grego prôton, primeiro, primitivo, anterior, original... [...] O texto teatral está sempre num contínuo movimento. Como texto dramático segue as "normas" de configuração do texto escrito que caminha do prototexto ao texto, mas ao ser transferido a outro sistema semiótico transforma-se em seguida em novo prototexto frente a esta nova fase (Camargo, 2008, p. 13-14).

Concorda-se com este entendimento, na medida em que a peça teatral submete-se às interferências de inúmeros dispositivos da encenaçáo que abalam o texto escrito e o arremessam como bólido opaco na representação, deixando-o sujeito a um feixe de signos, ora iluminado ora sombrio, que o enforma na urdidura da cena. É lá que a linguagem se torna um jogo e é batida e rebatida de um canto a outro, desdobrando-se em diversos signos. Grésillon vai mais longe ao defender que a cena já estaria encravada no texto teatral, em estado subjacente: 
[...] o componente cênico coexiste com o texto desde o projeto inicial, embora de modo latente, náo dito, até mesmo não dizível, como que recalcado pelo código da linguagem escrita. É a confrontação com as luzes da ribalta que lhe restitui a forma de um discurso explícito (Grésillon, 1995).

Utilizando-se, pois, destas referências instrumentais da crítica genética, que distinguem texto (o que é publicado) e prototexto (rastros, esboços, descaminhos, recaminhos, fluxos e refluxos que formam um conjunto de textos anteriores ao texto final) é possível estabelecer um paralelo, no teatro, como conceito operativo de análise: tomar a encenaçáo em si como equivalente ao texto e o itinerário criativo como equivalente ao prototexto, no caso, a protoencenaçâo; ou seja, os constituintes do percurso, que contribuíram para plasmar a obra ou aqueles que terminaram por se infiltrar no produto final, mesmo à revelia dos criadores. Assim, integram a protoencenação: elementos sonoros e visuais, atuação cênica, corpo, voz, falas e intençôes do texto, açóes físicas, movimentação, gesto, luz, enfim, o conjunto de signos teatrais que ora formam uma amálgama, ora atuam de forma emancipada, cada um falando por si, como convém à cena contemporânea.

\section{Técnica, Matéria e Materiais no Encalço da Concepção}

A opção pelos dramatículos como eixo da encenação reside na certeza de que ali estáo inculcados procedimentos radicais do autor: discursos justapostos ou paralelos da enunciaçáo, profunda imobilidade, depuração da palavra, fragmentação do corpo, ação decomposta e outros que consolidam um paradoxo no teatro de Beckett: é "puro teatro" e arte de fronteira, que dialoga com cinema, televisáo e romance. Cleise Mendes, tradutora dos textos de Comédia do Fim, lembra que, mesmo antes dos dramatículos, Beckett “[...] já havia minado os alicerces da dramaturgia realista, sobretudo, no 'terremoto' a que submete a ideia de personagem; da fala, os rangidos; do corpo, as ruínas" (Mendes, 2003, p. 5).

A montagem das cinco peças curtas, no mesmo espetáculo, traz questôes que envolvem a escolha e disposiçáo dos textos no espaçotempo de uma ordem cênica, sem desejar feri-los na constituição interna. Via de regra, os dramatículos são apresentados de forma autônoma, com intervalos entre um e outro, o que assegura não só a identidade de cada um, mas contribui para solucionar as mudanças 
técnicas exigidas pelo texto ou propostas pelas encenaçóes. No caso de Comédia do Fim, objetiva-se traçar um fio condutor do espetáculo, rejeitando-se a soluçáo peça a peça, embora se quisesse preservar a autonomia de cada uma.

Opta-se, então, pela criaçáo de uma personagem-chave, intitulada Ouvinte I, que se coloca à esquerda do palco, silencioso, como se estivesse a assistir o desenrolar do carretel da representaçáo, durante todo o tempo; ela é caracterizada pela cabeça raspada, longo sobretudo preto e a boca cerrada artificialmente, como se fosse suprimida do rosto (Figura 2). O propósito é estabelecer uma relaçáo com o público através dele e, ao mesmo tempo, solapar possibilidades de entendimentos fechados sobre o que está sendo ali apresentado: o que liga dois personagens táo semelhantes sentados numa mesa? $\mathrm{O}$ que significa cada batida? Do que eles estão falando? Quem está falando o quê?

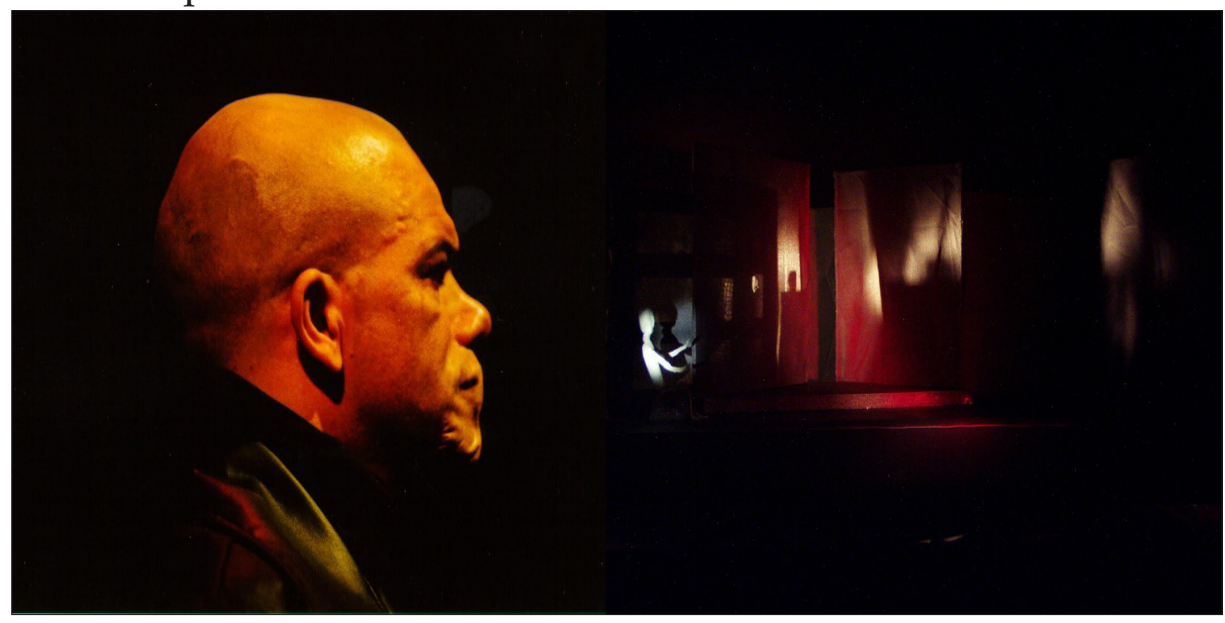

Figura 2: Composição da máscara facial da personagem Ouvinte I (Urias Lima), que atravessa toda a peça; à direita, maquete do cenário, com o Ouvinte I, posicionado à esquerda do proscênio. Foto: Adenor Gondim.

Por vários momentos, as tentativas de organização dos significados da representaçáo e de se construir um fio condutor que perpasse as cinco peças falham. O percurso então é definido em função da interferência dos elementos: ritmo, forma, silêncios, espaço e, principalmente, a soluçáo de questóes técnicas. Cada peça, na verdade, fala por si. Se há alguma ligação entre elas, isto é dado pelos ecos e ressonâncias dos princípios da poética beckettiana. Em vista disso, o espetáculo termina por direcionar-se para a resolução de problemas concretos da representação, especialmente as relaçóes encenação-texto, tempo-ritmo e ator-cenotecnia. De fato, a ordem das cenas se estabelece pelo jogo 
de pulsaçóes do espetáculo e submete-se ao ritmo geral, aos artefatos cenotécnicos e à correlação entre figura humana e materialidade física. O sentido vem depois. É o que diz Bim, em What where, de Beckett: "Dê sentido quem puder. Eu desligo" (Beckett, 1986, p. 476).

Tudo isso revela o reconhecimento dos dispositivos técnicos enquanto componentes determinantes da encenação, que não se tornam impedimento e se constituem materiais que imprimem resistências, limites e vontades ao encenador. É uma tensão que movimenta o fluxo criativo entre fazedor e matéria, como assinala Pareyson quando diz que o artista chega ao ponto de "[...] fazer a própria vontade precisamente fazendo a vontade da matéria", mas, ao mesmo tempo, "[...] procede de modo que as suas resistências sejam não rêmoras, mas solicitaçóes, e os seus limites não proibiçôes, mas sugestôes" (Pareyson, 1997, p. 165).

\section{Cenotecnia e Compressão do Espaço: interferências criativas}

A cenografia concebida para o espetáculo é uma grande caixa preta, com estruturas internas móveis, que desloca o espaço da ação de uma peça para outra. Quando a caixa se movimenta, estimula-se a impressão de que algo vai acontecer e ser revelado. $\mathrm{O}$ espectador ouve ruídos e vê, vagamente, a movimentaçáa de formas indefinidas no oculto do palco, ambos provocados pela manipulaçáo de painéis, que marcam as transiçóes de uma peça para outra. O objetivo é driblar a expectativa, uma vez que, cessada a movimentação, não há surpresas; apenas outra parte do espaço vazio é revelada, por formas triangulares que se encaixam e se desencaixam (Figura 3 ).

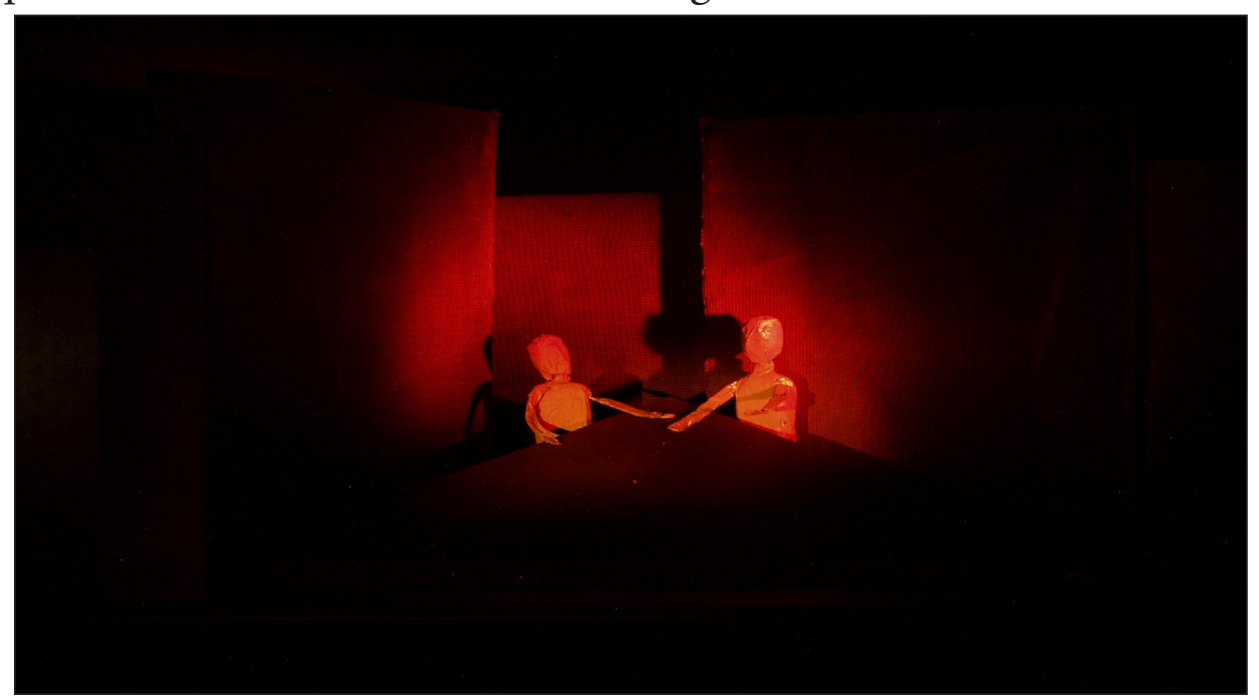

Figura 3: Maquete do cenário de Improviso de Ohio, com os atores posicionados numa das pontas da mesa triangular, formada a partir da movimentação e do jogo de encaixe dos painéis. 
Ao mesmo tempo, está em jogo a compressão do espaço sobre o corpo do ator - um dos desafios propostos por Beckett - já expressa pelo cenógrafo Moacyr Gramacho, após assistir aos primeiro ensaios: "A gente vai materializar o vazio. O cenário pode ser feito de painéis negros, opacos e transparentes, repartidos, uma espécie de caleidoscópio. É como se o ator fosse manipulado pelo aparato técnico" (Gramacho, 2004, p. 100). Os painéis lembram os écrans (biombos) de Gordon Craig, placas com múltiplas funções que ora refletem a luz, ora revelam corpos, ora se tornam opacas. Um dos objetivos é plastificar a figura do ator, colocá-lo preso e como que achatado numa moldura, comprimindo a movimentação, acentuando a desnaturalização.

Esta concepção espacial ressalta a visão de personagens-máquinas, assim chamadas por Peter Brook (1970, p. 57): "[...] invençôes puras, imagens frescas, agudamente definidas", "máquinas teatrais", tuteladas pelos dispositivos cênicos e confinamento espacial no palco à italiana. $\mathrm{O}$ ponto de partida, curiosamente, é a mesa indicada nas rubricas de Improviso de Ohio:

A gente tem uma mesa, que é um símbolo gráfico, extremamente realista. O primeiro exercício foi decompor a mesa, com todo respeito, deformar um pouco a mesa de Beckett. E na medida em que a mesa vira um ângulo, você pode transformá-la num praticável que se eleva e depois num apoio para os outros dramatículos. Isto ocorre com o mecanismo de forma invisível, fora do controle do elenco, dos personagens, e é o que cria espaços e vazios (Gramacho, 2004, entrevista).

O triângulo torna-se então fio condutor e ponto de partida da cartografia espacial. As peças se encaixam e dáo lugar a outras formas geométricas. De modo que, enquanto personagens se digladiam entre si e seus dúplices, a cenografia se desloca no espaço em tensa e cronometrada movimentaçáo. É interessante observar que nos ensaios, utilizou-se uma mesa hexagonal para construçáo da cena e da gestualidade dos intérpretes (Figura 4). Com o direcionamento para forma triangular, nota-se que apenas uma fatia da mesa hexagonal é absorvida, como que confirmando um dos princípios supressivos do teatro de Beckett: a redução. 


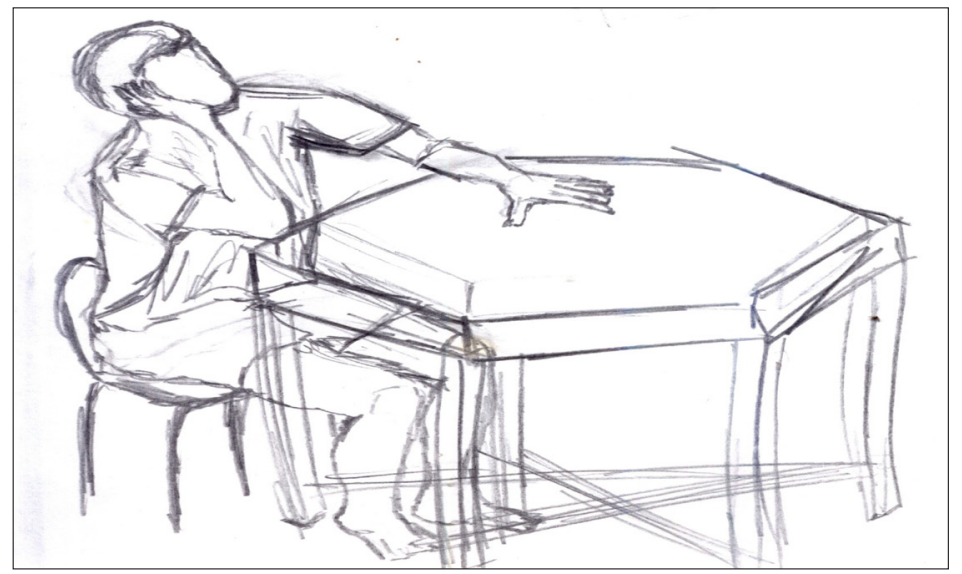

Figura 4: Esboço visual feito pelo observador Daniel Rabelo. A mesa hexagonal dos ensaios é recortada e reduz-se ao formato triangular na encenaçáo. Fonte: Fonte: Diário da montagem de Comédia do Fim.Protocolo de trabalho n. 32, 18 set. 2003.

\section{O “mínimo dos mínimos”: expiar e ressecar}

Para cada dramatículo do espetáculo, há uma estratégia particular de abordagem, mas ecos e ressonâncias de princípios comuns estáo em todos os demais: contração corporal, geometria espacial rigorosa, imobilidade física, subtração de movimentos, desconforto, construção de sintaxes musicais. Por isso, devido à formação dos atores, mais vinculada à atuaçáo psicológica e subjetiva, optei por uma estratégia, dividida em duas etapas, que foram traduzidas, respectivamente, em duas palavras-chave: lágrima e ressecamento. A primeira marca a etapa da verticalidade nas emoçóes primárias do ator e, assim, assume-se a subjetividade do processo de atuação - via do por. A segunda, centra-se na destilação dos conteúdos emocionais em direção a uma cena filtrada, seca, despossuída de significados, marcada pela construção de uma sintaxe musical na performance do ator ou na geografia de distribuição dos movimentos espaciais mínimos - via do tirar. A propósito, veja-se o que Beckett escreve num de seus últimos trabalhos, Pioravante marche: "Quando muito o mínimo dos mínimos. Maximamente menos que o mínimo dos mínimos" (Beckett, 1996, p. 9).

O momento deflagrador da primeira etapa é a instalação da cena - momento em que cada dramatículo tem as imagens-chave, materialmente definidas a partir de uma proposta de trabalho sensorial. Imagens são construídas e liberadas pelo elenco de forma a serem depois incorporadas, não necessariamente na encenação, mas no processo de composição individual, como estímulos sensoriais que integram a sintaxe imaginativa do ator, de modo que ele pudesse, depois, caminhar sem necessidade de identificaçáo projetiva com o papel (Figura 5). 


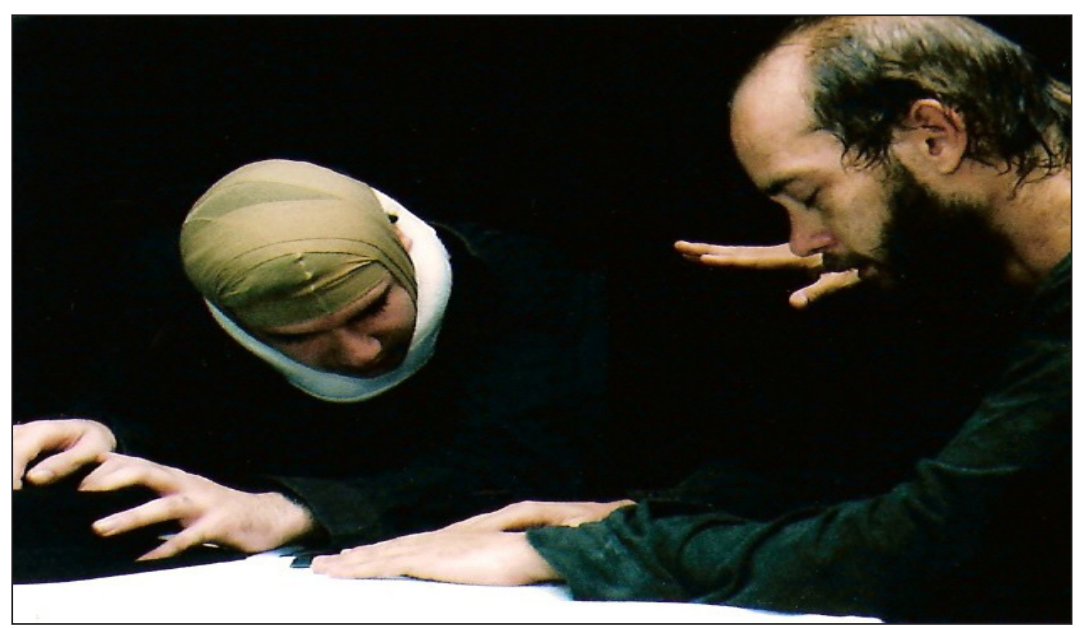

Figura 5: Os atores Ipojucan Dias (o Ouvinte) e André Tavares (o Leitor) em processo de ensaio de Improviso de Ohio. Fase da sensibilização emocional. Foto: Adenor Gondim.

Em Improviso de Ohio, optei por experimentar possibilidades do princípio da paridade, pistas dadas pelo texto e procedimento recorrente na poética beckettiana, que já apareciam nas primeiras peças (Esperando Godot, Fim de Partida, Dias Felizes) e se intensificam nas demais. Mas, isto não impediu intercorrências no processo, ajudando a engrossar a teia de fios nervosos do trabalho de construção das cenas. Um exemplo foi o exercício com máscaras fotográficas do rosto dos atores de Improviso de Ohio para enfatizar os princípios do dúplice. Os atores foram confrontados com suas experiências sensoriais, memórias físicas, o que exigiu intensa mobilização emocional dos intérpretes André Tavares (Leitor) e Ipojucan Dias (Ouvinte) (Figura 6).

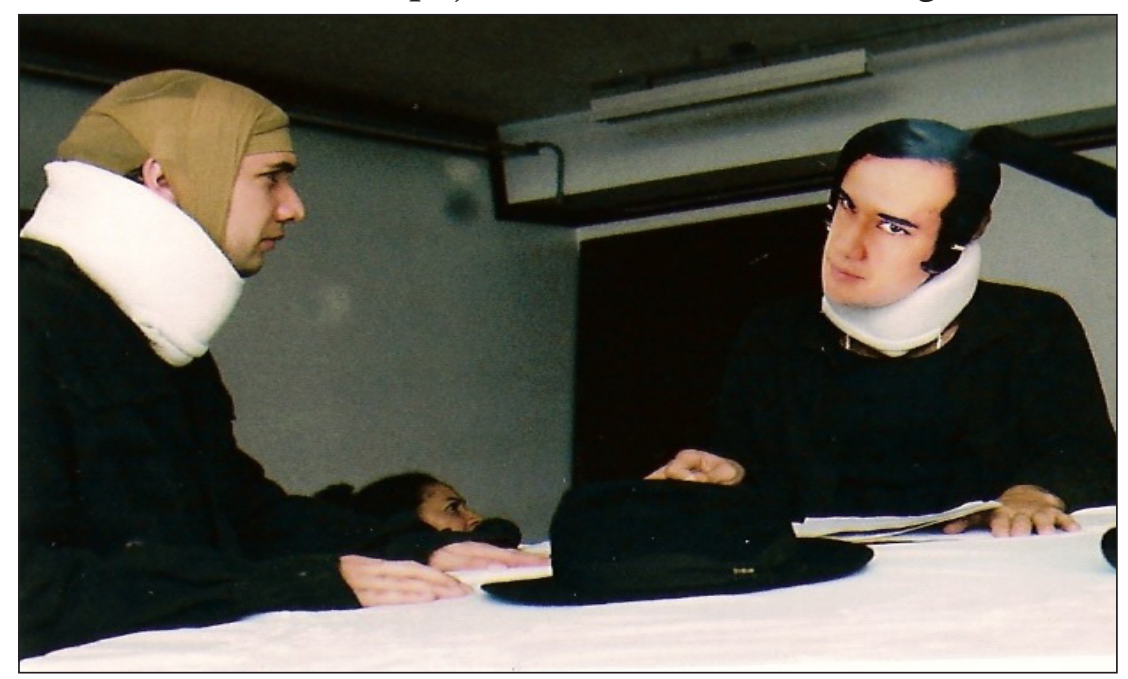

Figura 6: O ator Ipojucan Dias (o Ouvinte) contracenando com a máscara de seu rosto em André Tavares (o Leitor). Exercício do dúplice. Foto: Adenor Gondim. 
O testemunho da maquiadora Marie Thauront revela faceta curiosa deste momento:

[...] as imagens eram muito fortes e me marcou aquele ensaio: os prantos de André, a exposiçáo dos atores, os sentimentos deles, todos pegos de surpresa. Eu achei que era insuportável. Eu falava: Meu Deus, como é que eles vão aguentar? Mas ao mesmo tempo em que me senti desconfortável, eu gostei muito de ver aquilo. Me senti assim, como que voyeur. E quando concebia a maquiagem, sempre lembrava este momento (Thauront, 2004, entrevista).

Questóes como esta mostram que, mesmo que a obra de Beckett se abra a inúmeras leituras, há um ponto medial no hemisfério de possibilidades cênicas de atuação que se traduz na busca de um "equilíbrio delicado" entre dois polos, como pontua Pierre Chabert, diretor-assistente de Beckett:

O estilo de interpretaçáo [para o teatro de Beckett] reside num equilíbrio instável entre um aspecto mais realista, mais 'verdadeiro', e um outro mais distanciado, mais abstrato, mais formal ou musical, podendo ir até o expressionismo ou ao clownesco; eis aqui um domínio essencial em que o encenador, em conjunto com o ator, pode manifestar suas escolhas, sua sensibilidade, imprimir sua marca, afirmar sua visão (Chabert, 1994, p. 22).

A diretora Isabel Cavalcanti recoloca essa questáo dizendo que é necessário não confundir mecanicidade, materialidade e não psicologismo, que existem no jogo cênico das personagens de Beckett, com o trabalho artístico do ator:

As personagens podem ter mecanicidade, não o ator, porque o trabalho artístico não tem, o pintor não tem, o poeta não tem, o escritor não tem. Você está mexendo com emoções, questóes, a pessoa, o corpo, o suor, o raciocínio, a inteligência, este é o seu material. E isso não é mecânico, não adianta, é visceral (Cavalcanti, 2002, entrevista).

Ora, não se pode desconhecer essa contradição, já que é imperativo trazer para o corpo do ator as linhas de força que sustentavam a encenaçáo de Improviso de Ohio, sem as quais se instalaria uma dissociação indesejada entre concepção do espetáculo e atuação. Ainda assim, reiteraçóes práticas da vertente psicológica - necessidade de compreensão lógica da personagem ou identificação emocional -, frequentemente, incidiam na performance do intérprete, opondo-se, assim, à ideia da personagem-tornada-coisa. 


\section{Sintaxe Musical e o Pó das Palavras}

A partir da fase de liberaçáo emocional, o ensaio de Improviso de Ohio se dirige para a ênfase na musicalidade de palavras e gestos, na sintaxe do texto, no tempo-ritmo, o que implica em um retraço de caminhos, situados na fronteira entre a latitude de um método caótico-construtivo e o vácuo dos múltiplos significados do espetáculo. O objetivo é atingir um estado de não significação, não psicologização, não interpretação.

Tudo isso comprime mais a ação e obriga os atores à construção de gestualidades mínimas que caibam na dimensão contrita do espaço. Num dos estudos gráficos da montagem para articular a ordem das peças e garantir uma pulsação rítmica geral do espetáculo, vê-se que Improviso de Ohio é mantido no limite da relação menor velocidade e maior elasticidade do tempo (Figura 7). A escansão do dizer, o silêncio, as pausas, os retornos repetidos a determinadas frases configuram uma característica singular na representação deste dramatículo. Ao mesmo tempo, a máxima lentidão e o minimalismo dos movimentos terminam por aproximar a peça de uma imagem fixa, como que uma tela, moldura da qual as personagens, tal como aprisionadas na bidimensionalidade de um quadro, não podem sair.

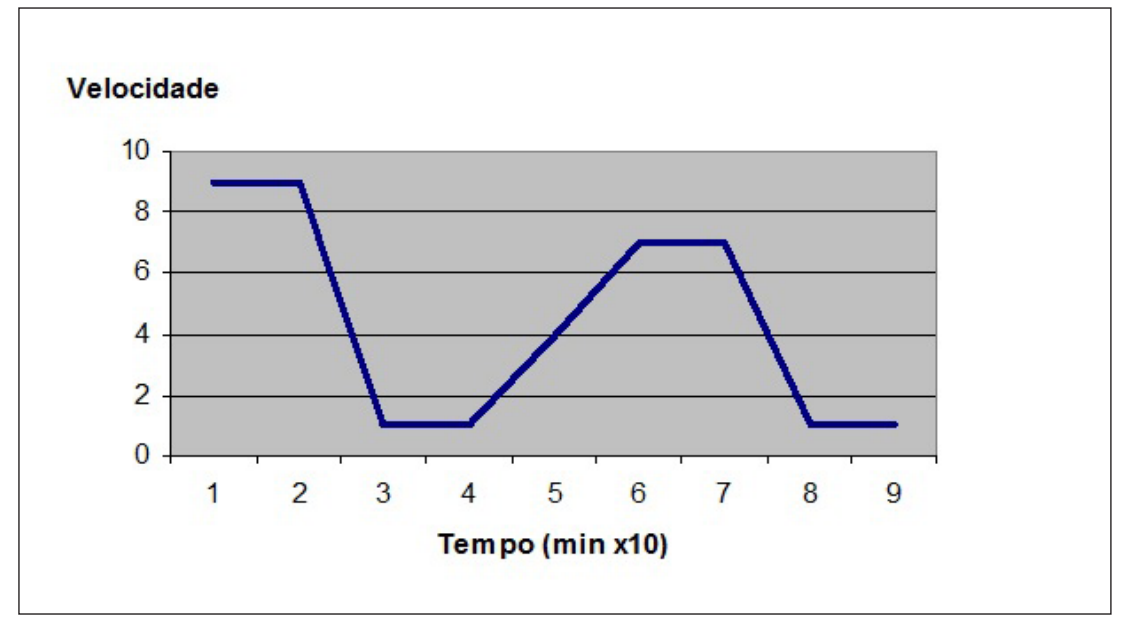

Figura 7: Estudo do tempo-ritmo do espetáculo: ritmo das cenas $\mathbf{X}$ tempo de duração. Gráfico construído a partir das observaçôes de Ney Wendell, assistente de direção de Comédia do Fim.

Fonte: Diário da montagem de Comédia do Fim. Protocolo de trabalho n. 45, 10 out. 2003.

O jogo entre ordenação da partitura e fragmentação póe a ordem no interior do caos e vice versa. Por isso, a estrutura do texto se torna estratégia para se chegar à musicalidade da encenaçáo, sem passar pela via psicológica, como observei durante os ensaios: " $\mathrm{Na}$ 
decomposição da personagem, a gente vai trabalhar com a fragmentação. Começamos hoje com a palavra. O corpo, o ambiente, a cultura fazem a forma de dizer de cada ator. Esta é uma boa técnica para dessignificar a palavra. Abrir-se à musicalidade, à sonoridade, ao ritmo" (Diário da montagem, 2003, p. 114).

Optei, entáo, por decompor o alfabeto, letra a letra, escandindo as palavras para reorganizar a gramática do texto no eixo corpo-voz, na perspectiva da sintaxe da encenaçáo. $O$ pressuposto era que aquelas frases, ditas e reditas, esvaziavam-se de significados, deixando as palavras em sua forma pura, princípio da repetição anunciado no texto:

Algum tempo depois, ele voltou, à mesma hora, com o mesmo livro, e desta vez sem nenhum preâmbulo sentou-se e tornou a lê-lo ao longo de toda a noite. Depois desapareceu sem uma palavra. (Pausa) Assim, de tempos em tempos de improviso ele aparecia para reler a mesma triste história e dar alívio à longa noite. Depois desaparecia sem uma palavra. (Pausa) (Beckett, 2003, p. 2).

Escolhi, assim, o caminho do desordenamento da linguagem; trabalhar, de forma aleatória, pedaços do texto, deslocados do contexto para depois recompô-los. Começar com letras, sílabas ou palavras de qualquer parte da peça, operando-se movimentos para frente e para trás, sem observar a ordem, gramatical; colocar em prática a técnica do fragmento, decompor a peça em unidades mínimas, retiradas de qualquer lugar do texto, sem se aprisionar aos significados. Isso fez com que o trabalho com o ator André Tavares (o Leitor) tenha caminhado para uma realfabetização cênica do texto; ou seja, a criação de uma anatomia sonora, que pudesse chegar o mais próximo da palavra em seu estado de não-significação, como se pudéssemos atingir o osso, a depuração.

O objetivo era obter uma forma de polimento do texto, no sentido de estatuí-lo enquanto léxico cênico, tornando a personagem uma letra do alfabeto teatral. A protocolista Adriana Amorim, que fez o registro cursivo do processo de ensaios, dá o testemunho dessa operação, que envolve seguidos esforços de tratamento gramatical:

Tenho a impressão de que as palavras foram polidas, saiu o pó. A imagem da palavra cristalina é muito boa. E também a técnica acaba por isolar as palavras dentro da frase. É diferente a frase como um todo e a frase no conjunto de vários todos (Diário da montagem, 2004, p. 40).

No entanto, o trabalho com o texto e a limpidez das palavras não foi suficiente para se atingir o estado de imobilidade desejado para a 
montagem da peça. Costuma-se dizer que, em Beckett, a fala é ação. Mais do que isso, que há um caminho supressivo de elementos em sua poética: do movimento à imobilidade, da palavra ao silêncio, do falar veloz ao dizer escandido, do dito ao náo dito. Em determinadas peças há um proeminência de um elemento em relação a outro. No caso de Improviso de Ohio, percebe-se que, mesmo centrando-se no texto, o corpo exige do intérprete um condicionamento e treinamento precisos, que passam pela relação imobilidade-movimento e pela experimentação de princípios contidos em outras peças..

Um exemplo disso foi a cadeira de rodas, presente apenas no dramatículo Fragmentos de Teatro I, cujos personagens são o Cego e o Aleijado, mas que se tornou passagem obrigatória para todos os atores, o que acentuava uma dinâmica recorrente: a relação imobilidade e movimento. Veja-se: estar imóvel e impedido de andar; usar gestos sem deslocamento espacial e sem mexer em braços e pernas; ao mesmo tempo, a cadeira é posta em movimento por outro ator, o que cria o paradoxo de se estar imóvel e ser movido. Dessa ambígua associação, nasce uma intensidade física e sensorial, que se ressignifica na atuação, de forma que esta não se torne mera repetição de gestos e palavras.

Aliás, o objetivo era repetir ação, palavra ou situação, mas de forma integrada a um conjunto de outros procedimentos para que a atuação não resvalasse na exibição técnica ou instrumental. No esboço visual de um ensaio de Improviso de Ohio (Figura 8), pode-se notar o exercício com braços e pescoços, feitos exaustivamente pelos atores, para que pudessem adquirir a imobilidade desejada; no lado esquerdo, a passagem pela cadeira de rodas. Ao se comparar o desenho com a foto da peça (Figura 9), pode-se notar que as duas personagens de Improviso de Ohio posicionam-se como se estivessem numa cadeira de rodas, imobilizados; apenas alguns gestos lhes são permitidos; ou seja, excede-se na dinâmica do movimento nos ensaios para depois suprimi-la, em nome de um vigor mortis. 


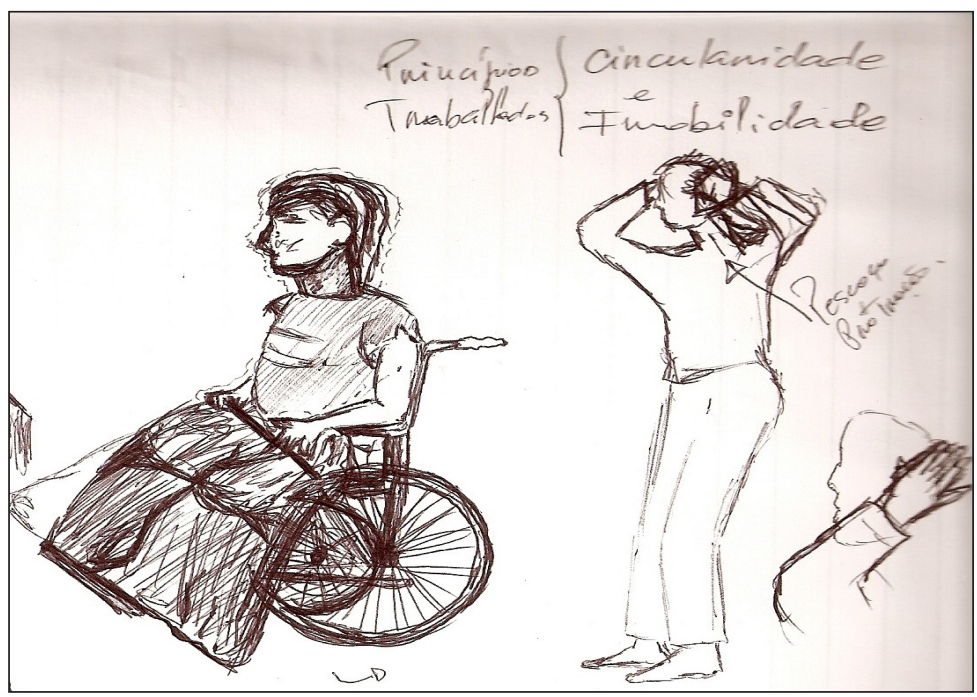

Figura 8: Registro livre de impressôes sobre os ensaios de Improviso de Ohio, que ilustra várias tentativas e estratégias de abordagem física para se chegar à imobilidade. Esboço visual de Daniel Rabelo. Fonte: Diário da montagem de Comédia do Fim. Protocolo de trabalho n. 30, 16 set. 2003.

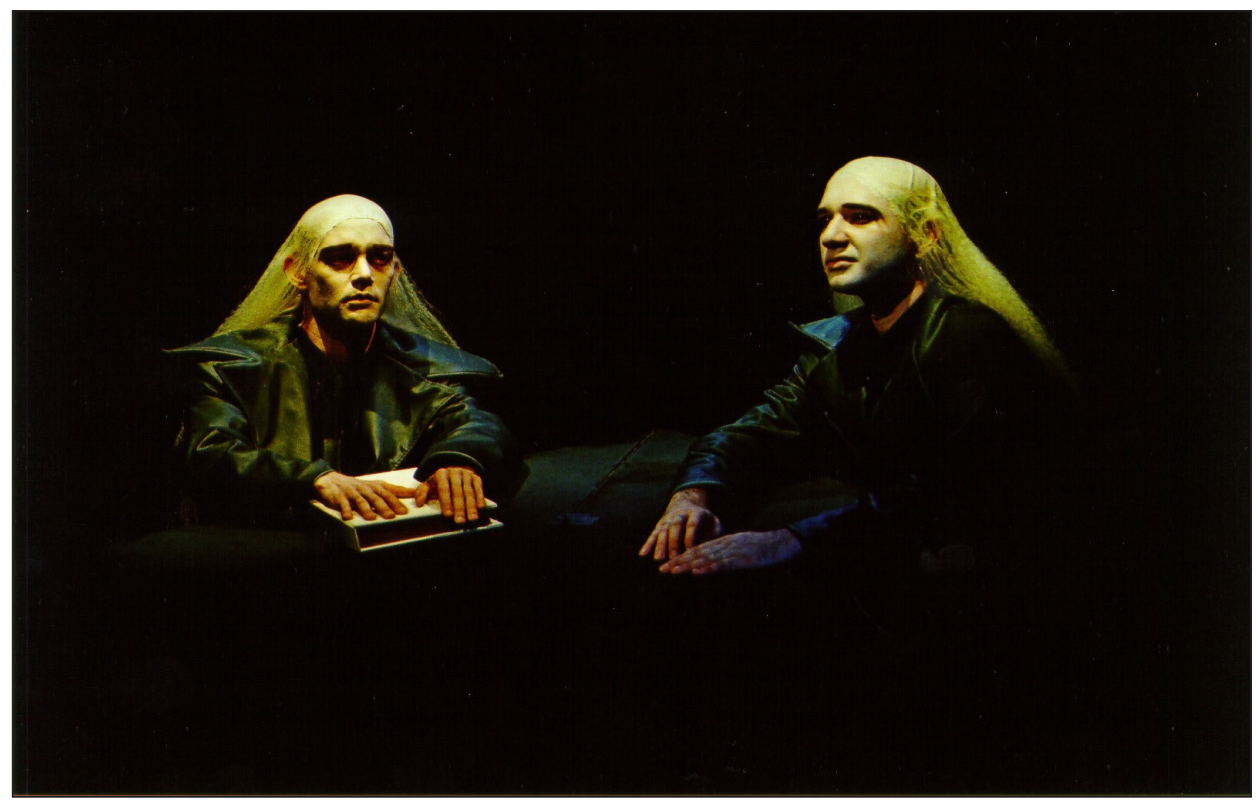

Figura 9: Foto de Improviso de Ohio. Atores imóveis, em silêncio. Foto: Adenor Gondim.

Durante os ensaios, procurei acentuar a dificuldade de dissociar técnica, emoção e tramas da linguagem que atravessam a dramaturgia de Beckett: "A técnica envolve-se na palavra. Ao invés de procurar emoção e depois incluir a técnica, vamos trabalhar as duas juntas e deixar a emoção para o espectador, se houver. Cada um vai relacionar-se com a palavra de um jeito" (Diário da montagem, 2003, p. 40). Daí que desenroscar os nós da linguagem, comprimir o corpo e fazer a palavra ricochetear até atingir o estado cênico de 
depauperamento e esvaziamento são constituintes fundamentais da cena e um dos paradoxos mais vivenciados no processo. $\mathrm{O}$ desafio era construir um discurso polifônico, mas que dissolvesse as vozes numa monofonia.

Pode-se afirmar que as dificuldades quanto à aplicação da linha geral para o trabalho do ator permeou boa parte do processo e também do resultado cênico, fazendo com que rastros indesejados interferissem na encenaçáo. O depoimento de André Tavares (O Leitor, em Improviso de Ohio), após a estreia, sintetiza bem esse impasse:

Era muito engraçado que às vezes eu ia pra cena e queria fazer uma voz toda empostada e puxava a emoção pra vir. Com o tempo, mudei de atitude. Em vez de me preocupar em interpretar ou representar, ou seja lá o que for, eu vou me ater ao que tenho pra fazer aqui (Tavares, 2006, entrevista).

No resultado final, ainda que se considere as interferências dos constituintes da protoencenação, é visível o resultado de uma performance não-naturalista, que constrói a musicalidade geral do espetáculo, pela relaçáo entre vocalidades dos atores, movimento e partitura do texto. A peça Improviso de Ohio toma forma, modalizada por um pulsar de vozes distintas e ruídos das falas; a sonoridade se junta à imobilidade, à movimentaçáo controlada e à grafia visual da materialização do vazio, transita na câmara de ecos das consonâncias e dissonâncias e se infiltra na gramática da fragmentação que ordena o espetáculo ${ }^{6}$.

\section{"Sem sombra de ternura"}

Examinar uma experiência que se deu há 10 anos é abrir-se a um olhar crítico, mas sempre incompleto. $\mathrm{E}$ a encenação, por sua característica coletiva, é um feixe conjuntivo de olhares que moldam o processo criativo, mas que traz o impensado e impóe signos náo intencionalmente declarados, que se legitimam no fazer da obra, abrindo-se a múltiplos significados, em diferentes ângulos. A encenação assemelha-se, assim, a um gradiente, para usar uma expressão cara a Merleau-Ponty, ou seja, "[...] uma rede que se lança ao mar sem saber o que recolherá" ou uma "estreita ramificação sobre a qual se farão cristalizações imprevisíveis" (Merleau Ponty, 2004, p. 14). Dessas cristalizaçóes, cujo fluxo não se controla, e dos frutos recolhidos pela rede incerta, a encenação, também, se constrói, revelando-se 
pelo visível e por aquilo que náo se mostra ou não se diz, mas ali está, impondo sua presença.

Nesse espaço, a linguagem se aloja e confronta a rigorosa trama de imagens, sonoridades e corporeidades da encenação, cuja função é manter tensa oscilação entre significado e esvaziamento. Nas primeiras apresentaçóes de Improviso de Ohio, percebia-se certa emocionalidade indesejada, advinda do contato do ator com o público. Mas o caminho do ressecamento, em alguns casos, só foi encontrado no decorrer da temporada. São as "cristalizaçóes imprevisíveis" que aspiram à lapidação, tal como expresso nas palavras do ator André Tavares (2004, entrevista), após a estreia do espetáculo:

Depois de Beckett mudou muito. Ele exige essa espontaneidade no interpretar que apesar de estar marcado, com tempo, pausa, isso ou aquilo outro, com essa interpretação da palavra. Eu aprendi a náo interpretar. E acho que este foi o meu maior aprendizado com Beckett.

Examinando, hoje, a montagem de Comédia do Fim, percebo que não foi de todo possível escapar das armadilhas de organização de significados. No caso de Improviso de Ohio, o desafio era conter duplamente a intenção de emocionalizar a cena tanto na visão do ator quanto na do diretor. De um lado, imperava o desejo de que o espectador criasse um vínculo emocional com aquela imagem que se desenhava lentamente à sua frente; de outro, evitava-se que a emoção o levasse a zonas porosas que refutassem a experiência do contato direto com o objeto, para que ele contemplasse uma paisagem cênica. Esse controle foi impossível. Alguns espectadores viram em Improviso de Ohio uma paisagem-humana ressecada, portanto mais contemplativa e menos sensorial; outros criaram vínculos emocionais e se disseram transportados para a história ali apresentada, na perspectiva de um mecanismo projetivo-identificativo.

Os rastros do processo criativo que compuseram a protoencenação de Improviso de Ohio muitas vezes tomaram forma de figura no resultado final, à revelia do desejo do criador e independentemente da concepçáo proposta; matéria e materiais do itinerário formador emanciparam-se da condiçáo de vestígios e esboços, alçando-se à condição de "forma formada" na encenação, constituinte absorvido na composição da obra. A lágrima, por exemplo, antes estimulada na primeira etapa do processo e desestimulada no resultado final, tornou-se matéria da cena. O ator Ipojucan Dias, invariavelmente, 
construía uma lágrima no momento em que ouvia a seguinte passagem do texto: "Tinha visto o rosto querido e ouvido as palavras muda. Fica onde por tanto tempo estivemos juntos a sós, minha sombra te consolará" (Beckett, 2003, p. 2). Era algo não previsto na ordem da peça de Beckett nem desejado inicialmente pela concepção, mas que terminou aderindo-se à encenação. Rastros que se tornaram figuras.

Toda esta discussão repousa sobre um fundo de clareza e obscuridade, que é o embate entre a experiência artística e a insuficiência da linguagem em traduzi-la na completude. Não por acaso, em direçáo ao abismo aberto da encenação, vertigem do sonoro e do visual, a matéria escrita do texto se debate no espaço-tempo com a luz, som e movimentos, ocorrências derivadas de sua instabilidade diante da materialidade da cena. É o permanente estado de querer desvanecerse, mas náo por completo, de ameaçar deliquescer-se, mas sem nunca cumprir a promessa. Talvez por isso, a todo o momento, a encenaçáo parece querer arrebentar a pele tênue que cobre a delicadeza e a porosidade das matérias que a constituem. Em sua interioridade, há uma usina de signos prestes a explodir, mas nunca o fará, irradiando-se das máquinas humanas que são, agora, o corpo do ator e as saliências das linguagens que perfazem o trânsito nervoso entre as esferas do caos e da ordem, no território minado da representação teatral. 


\section{Notas}

${ }^{1}$ Esta expressão é utilizada por Williams, quando examina o teatro de Pirandello, Ionesco, Beckett e Tchekhov, especialmente este último. Cf. WILLIAMS, Raymond. Tragédia Moderna. São Paulo: Cosac Naify, 2002, p. 189.

${ }^{2}$ Ver, a esse respeito: MORENO, Arley R. Wittgenstein: os labirintos da linguagem. Sáo Paulo: Moderna; Campinas: Universidade de Campinas, 2006, p. 51.

${ }^{3}$ Comédia do Fim foi uma realizaçáo do Núcleo de Teatro do Teatro Castro Alves - TCA. No elenco os atores profissionais Frieda Gutman, Zeca de Abreu, Hebe Alves, André Tavares, Luiz Pepeu, Ipojucan Dias e Urias Lima. O espetáculo teve cinco indicações ao Troféu Braskem de Teatro, que premia os melhores espetáculos profissionais do ano: atriz (Frieda Gutmann e Hebe Alves), direção, cenografia e espetáculo, obtendo premiação nas duas últimas categorias.

${ }^{4}$ A pesquisadora Perrone-Moysés aproxima esta peça do gênero clássico consolatio (consolação) muito utilizado por Sêneca, Maynard e Malherbe.

${ }^{5}$ Afirmação atribuída a Beckett por: McMILLAN, Dougald; FEHSENFELD, Martha. Beckett in the Theatre: the author as practical playwright and director. London: John Calder, 1988; New York: Riverrun Press, 1988, v. 1.

${ }^{6}$ Veja-se o comentário de Ana Cláudia Cavalcanti a esse respeito: "Se o produto fosse sonoro, esta seria uma obra que náo utilizaria a harmonia tradicional, estaria mais próxima da música atonal". CAVALCANTI, Ana Cláudia. Comédia Atonal. A Tarde, Salvador, 26 jan. 2004. Disponível em: <http://www.atarde.com.br>. Acesso em: 27 jan. 2004.

7 Termo utilizado por Pareyson (1997, p. 188) ao propor a dialética da forma formante $e$ da forma formada: "[...] se é verdade que a forma existe somente quando o processo está acabado, como resultado de uma atividade que a inventa no próprio ato que a executa, é também verdade que a forma age como formante, antes ainda de existir como formada, oferecendo-se à adivinhaçáo do artista, e, por isso, solicitando seus eficazes presságios e dirigindo suas operaçôes".

\section{Referências}

ASMUS, Walter. Walter Asmus. In: OPPENHEIM, Lois. Directing Beckett. Michigan: The University of Michigan Press, 1997. P. 42. [Entrevista concedida ao autor da obra citada].

BARTHES, Roland. Roland Barthes por Roland Barthes. Tradução de Leyla PerroneMoisés. São Paulo: Cultrix, 1977.

BECKETT, Samuel. Últimos Trabalhos de Samuel Beckett. Lisboa: O Independente; Assírio \& Alvim, 1996.

BECKETT, Samuel. The Complete Dramatic Works. London: Faber and Faber, 1986.

BECKETT, Samuel. Carta de Samuel Beckett a Axel Kaun: a carta alemã, de 1937. In: 
ANDRADE, Fábio. Samuel Beckett: o silêncio possível. São Paulo: Ateliê Editorial, 2001. P. $167-171$.

BECKETT, Samuel. Improviso de Ohio. Tradução de Cleise Mendes para a montagem de Comédia do Fim. Salvador: Teatro Castro Alves, 2003. [Não publicado].

BROOK, Peter. O Teatro e seu Espaço. Petrópolis: Vozes, 1970.

CAMARGO, Robson. A Crítica e a Crítica Genética: diálogos sobre o entendimento do espetáculo teatral. Academia.edu, p. 1-32, dez. 2008. Disponível em: <http://www. academia.edu/168182/Teatro_e_Recepcao._A_Critica_e_a_Critica_Genetica._Dialogos_sobre_o_entendimento_do_espetaculo_teatral >. Acesso em: 10 jan. 2013.

CAVAlCANTI, Ana Cláudia. Comédia Atonal. A Tarde, Salvador, 26 jan. 2004. Disponível em: <http://www.atarde.com.br>. Acesso em: 27 jan. 2004.

CAVALCANTI, Isabel. Isabel Cavalcanti: depoimento [jun.2002]. Entrevistador: Luiz Marfuz. São Paulo, 2002. 01 cassete sonoro (60 min). [Entrevista concedida ao autor deste artigo].

CHABERT, Pierre. Singularité de Samuel Beckett. Théâtre Aujourd'oui. Paris: CNDP, n. 3, p. 22, 1994. [Edição dedicada ao universo cênico de Samuel Beckett].

DIÁRIO DA MONTAGEM de Comédia do Fim. Salvador: Teatro Castro Alves, 2003. [Registro cursivo, feito por Adriana Amorim].

DIÁRIO DA MONTAGEM de Comédia do Fim. Salvador: Teatro Castro Alves, 2004. [Registro cursivo, feito por Adriana Amorim].

FOUCAULT, Michel. As Palavras e as Coisas. Tradução de Salma Tannus Muchail. 7. ed. São Paulo: Martins Fontes, 1995.

GRAMACHO, Moacyr. Moacyr Gramacho: depoimento. [ago. 2004]. Salvador, 2004. 01 CD. [Entrevista concedida a Daniel Rabelo, bolsista do Programa de Iniciação Científica - PIBIC-UFBA].

GRÉSILLON, Almuth. Nos Limites da Gênese: da escritura do texto de teatro à encenação. Estudos Avançados, São Paulo, v. 9, n. 23, jan./abr. 1995. Disponível em: <http:// www.scielo.br/scielo.php?pid=S0103-40141995000100018\&script=sci_arttext $>$. Acesso em: 13 jan. 2013.

McMILLAN, Dougald; FEHSENFELD, Martha. Beckett in the Theatre: the author as practical playwright and director. London: John Calder, 1988; New York: Riverrun Press, 1988. V. 1.

MENDES, Cleise. Sobre Comédia do Fim. PROGRAMA DE COMÉDIA DO FIM, Salvador: Teatro Castro Alves, nov. 2003.

MERLEAU-PONTY, Maurice. Fenomenologia da Percepção. São Paulo: Martins fontes, 2006.

MERLEAU-PONTY, Maurice. O Olho e o Espírito. São Paulo: Cosac Naify, 2004. 
MORENO, Arley R. Wittgenstein: os labirintos da linguagem. São Paulo: Moderna; Campinas: Universidade de Campinas, 2006.

PAREYSON, Luigi. Os Problemas da Estética. 3. ed. São Paulo: Martins Fontes, 1997.

PERRONE-MOYSÉS, Leyla. Uma Solitária Peça de Amor. Folha de S. Paulo, São Paulo, 02 set. 1996. Caderno Mais, p. 5.

RUSHE, Rubens. Rubens Rushe: depoimento. [jun. 2002]. Entrevistador: Luiz Marfuz. São Paulo, 2002. 03 fitas cassetes (180 min), estéreo. [Entrevista concedida ao autor deste artigo].

TAVARES, André. André Tavares: depoimento [out. 2006]. Salvador, 2006. 01 cassete sonoro (60 min). [Entrevista a Victor Cayres, bolsista do Programa de Iniciação Científica - PIBIC-UFBA].

THAURONT, Marie. Marie Thauront: depoimento [ago. 2004]. Salvador, 2004. 01 CD. [Entrevista concedida a Daniel Rabelo, bolsista do Programa de Iniciação Científica - PIBIC-UFBA].

VALÉRY, Paul. Introdução ao Método de Leonardo da Vinci. São Paulo: Editora 34, 1998.

WILliAMS, Raymond. Tragédia Moderna. São Paulo: Cosac Naify, 2002.

Luiz Marfuz é doutor em Artes Cênicas pela Universidade Federal da Bahia (UFBA), mestre em Comunicação e Cultura Contemporâneas e bacharel em Comunicação e em Administração, também pela UFBA. É diretor teatral, professor-adjunto da Escola de Teatro da UFBA. Publicou o livro Harildo Déda: a matéria dos sonhos (2011) em coautoria com Raimundo Leão. É coordenador do Grupo de Pesquisa PÉ NA CENA - Poéticas de Atuação e Encenaçáo, vinculado ao CNPq.

E-mail: lumaz@uol.com.br

Recebido em 02 de fevereiro de 2013 Aprovado em 10 de abril de 2013 